\title{
AC 2007-895: CAPSTONE DESIGN COURSE AS A TOOL FOR ASSESSMENT AND IMPROVEMENT
}

\section{Showkat Chowdhury, Alabama A\&M University}

Dr. Showkat Chowdhury is an Associate Professor in the Department of Mechanical Engineering at Alabama A\&M University in Huntsville, AL. Dr. Chowdhury has extensive background in teaching undergraduate and graduate students in Mechanical Engineering, and performing research in the fields of Computational Fluid Dynamics, Combustion, Propulsion, Heat \& Mass Transfer and Turbulence. Previously, he worked as a Professor at Bangladesh University of Engineering \& Technology (BUET) and at University of Brighton, U.K. He also worked in the Research Division of Corning Inc. He earned his Ph.D. and M.S. in Mechanical Engineering from Clarkson University, New York and B.S. in Mechanical Engineering from BUET.

\section{Abdul Jalloh, Alabama A\&M University}

Dr. Abdul Jalloh is an Assistant Professor in the Department of Mechanical Engineering at Alabama A\&M University in Huntsville, Alabama. Dr. Jalloh has extensive background in teaching undergraduate and graduate students in Mechanical Engineering, and conducting research in composite materials, manufacturing processes, structural dynamics and the finite element method. He also spent many years in industry as a project engineer. He earned his BS in Mechanical Engineering from the University of Sierra Leone, and his MS and PhD degrees, also in Mechanical Engineering, from the University of Arizona in Tucson, Arizona.

\section{Ruben Rojas-Oviedo, Alabama A\&M University}

Dr. Ruben Rojas-Oviedo is Chairperson and Associate Professor of the Department of Mechanical Engineering at Alabama A\&M University in Huntsville, AL. Dr. Rojas-Oviedo has international engineering experience working both in academy and industry. He has an engineering consulting company and conducts applied research. He earned a Ph.D. in Aerospace Engineering from Auburn University, he has two Masters degree one in Mechanical Engineering from N.C. State at Raleigh and the other in Applied Mathematics from Auburn. He earned a B.S. degree in Aeronautical Engineering from the National Polytechnic Institute - Escuela Superior de Ingenieria Mecanica y Electrica - in Mexico City, Mexico.

\section{Mohamed Seif, Alabama A\&M University}

Dr. Mohamed A. Seif is a Professor in the Mechanical Engineering Department at AAMU. He joined AAMU in September 2002. His research experience includes Fatigue and Fracture Analysis, NDE, Health Monitoring of Structures, Quality and Reliability Assessment, Design Optimization, CAD, Robotics, and Laser measurement. He obtained his Ph. D. degree from the University of Central Florida in July 1988. He is a registered Professional Engineer in the State of Alabama. His research funding exceeds $\$ 1.9 \mathrm{M}$ and has over 80 refereed and non-refereed publications. Dr. Seif has worked as a consultant engineer for several companies such as FMC Corp, Daniels Manufacturing Corp, Inner Millennium Research, and ESA Inc.

\section{Amir Mobasher, Alabama A\&M University}

Dr. Amir Mobasher is Associate Professor of the Department of Mechanical Engineering at Alabama A\&M University in Huntsville, AL. He holds a Ph.D. degree in Mechanical Engineering from University of Alabama in Huntsville. He has research interest in the areas of Computational Fluid Dynamics, Biomechanics, and Control and Automation. His primary area of interest at AAMU is Automation, Control and Fluid Dynamics. After graduating from UAH, he worked at U.S. Army Aeromedical Research Laboratory at Fort Rucker, Alabama. During his employment there, his research focused on aircrew protection and head-supported mass and center of mass placement for the U.S. Army aviation. 


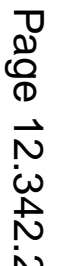




\title{
Capstone Design Course as a Tool for Assessment and Improvement
}

\begin{abstract}
This paper discusses the role of the Capstone Design course in achieving the goal of the Mechanical Engineering (ME) Program at Alabama A\&M University. The course is mapped to the ME Program educational objective and expected outcomes, as well as to the Accreditation Board for Engineering and Technology (ABET) criteria and some additional ME Program criteria based on the requirements by the American Society of Mechanical Engineers. The program outcomes should be measurable, and so an assessment tool or Survey has been developed. The survey form is completed by the students at the end of the second semester of the Capstone Design course, along with their final project report. Evaluations by the instructors are also completed. The student survey results and faculty evaluations are compiled and compared with the above mentioned course mapping. The results show that there is considerable matching between the course mapping for the expected educational outcomes done by the faculty, and the survey completed by the graduating students in this respect. This serves as a tool for measuring the accomplishment of ABET requirements. The results also give some feedback for possible improvement in future.

The Capstone Design course also serves to prepare the students to succeed as entry-level engineers in industry, by acquiring technical design experience for appropriate careers. The students are required to make several oral presentations with audio-visual aids (using PowerPoint) about their project in front of the faculty and peers, during the semester. A Project Oral Presentation Evaluation Form has been developed which is completed by the faculty and peers during each presentation. The results are compiled and analyzed. The results show that there is significant (over 20\%) improvement in the student performance due to this continuous evaluation by the faculty and peers. The Capstone Design course uses the knowledge learned by the students in various academic courses, and trains them how to complete a project as an engineer utilizing that knowledge. It also teaches the student to work effectively in a team, which is one of the top requirements of Best Practices for new B.S. graduate engineers by industry. By preparing the students to be successful engineers, the Capstone Design course improves student retention and will help to increase the percentage of minority black engineers in future.
\end{abstract}

\section{Background}

Alabama Agricultural and Mechanical University (AAMU), a historically black university, reflects the uniqueness of the traditional land-grant institution, which combines professional, vocational and liberal arts pursuits. The University provides baccalaureate and graduate studies that are compatible with the times to all qualified and capable individuals who are 
interested in further developing their technical, professional, and scholastic skills and competencies. AAMU is located in Huntsville, Alabama, which is known internationally as a center of aerospace and defense technology. Huntsville is considered as a leader in high-tech research, engineering services, information systems design and in the manufacturing of computing equipment, telecommunications, space vehicles and rocket propulsion. It is the home of more than 50 Fortune 500 companies. These industries and government agencies require a large number of qualified engineers in the areas of manufacturing and propulsion.

The Mechanical Engineering (ME) program at Alabama A\&M University started in 1997, as a result of a desegregation lawsuit. The program encompasses the traditional roles of Mechanical Engineering in areas of analysis, design, manufacturing, and testing of mechanical and thermal systems, while also including system integration, propulsion systems, concurrent engineering, and other competitive manufacturing practices. Based on the local demand, the program has two options: Manufacturing and Propulsion. The Mechanical Engineering Department is committed to prepare students in these options, to work efficiently for various industries and government.

The basic criteria of the Accreditation Board for Engineering and Technology (ABET) for the engineering program's outcome and assessment requires that graduates must have demonstrated abilities (ABET Criteria 3, a-k ${ }^{1}$ ), in mathematics, science, engineering, design, data analysis, teamwork, ethics, communications, and life-long learning. In addition to ABET 3(a-k) requirements, the Mechanical Engineering program at AAMU was designed to meet the additional requirements of the American Society of Mechanical Engineers, criteria (1-s), which require that graduating students must have knowledge about calculus, differential equations, statistics, thermal and mechanical systems, computational and experimental practices, data collection, chemistry, and calculus-based physics. The Faculty at Alabama A\&M University adopted the SEAARK teaching method ${ }^{2-4}$. SEAARK stands for Knowledge, Repetition, Application, Analysis, Evaluation and Synthesis in reverse order.

The Mechanical Engineering Faculty at AAMU revised the course contents to satisfy the above criteria $(a-s)^{5-6}$. Although each course does not necessarily satisfy all the (a-s) requirements, the overall $\mathrm{ME}$ curriculum provides the (a) through (s) training. The Mechanical Engineering program was successfully accredited by ABET in Summer 2000 and in Fall 2002.

Though most of the ME programs at different schools probably have some sort of Capstone Design Course, the purpose of this paper is to investigate the ways this course can be used to improve the performance of the students, and measure those improvement. Also, it provides an opportunity for other programs or schools to compare with their Capstone Design Course.

\section{Assessment Tools}

The educational objective of the Mechanical Engineering program is to provide students with the necessary preparation in Mechanical Engineering to compete effectively for professional careers in this field and with the motivation for personal and professional growth through life- 
long learning. The objective of each course has to be designed to meet the overall ME program objective.

The Accreditation Board for Engineering and Technology (ABET) Criteria 3, (a-k) ${ }^{1}$ for the engineering program's outcome and assessment, and the Mechanical Engineering program at AAMU's additional criteria (1-s) to meet the requirements of the American Society of Mechanical Engineers are shown in Table 1. The Mechanical Engineering program at AAMU's Educational Objective and Expected Educational Outcomes are also listed in Table 2.

Table 3 shows the mapping of the ME program Educational Objective and Expected Educational Outcomes for Capstone Design Course (ME470 and ME475) to ABET Criteria 3(a-k) and additional criteria (l-s). Based on this mapping, the outcome of the Capstone Design Course has to be measured for the mapped criteria.

Table 1. ABET Criteria (a-k) and additional ME Program Criteria (l-s).

\begin{tabular}{|c|l|}
\hline a & An ability to apply knowledge of mathematics, science and engineering. \\
\hline $\mathrm{b}$ & $\begin{array}{l}\text { An ability to design and conduct experiments, as well as to analyze and } \\
\text { interpret data. }\end{array}$ \\
\hline $\mathrm{c}$ & An ability to design a system, component, or process to meet desired needs. \\
\hline $\mathrm{d}$ & An ability to function in multidisciplinary teams. \\
\hline $\mathrm{e}$ & An ability to identify, formulate and solve engineering problems. \\
\hline $\mathrm{f}$ & An understanding of professional and ethical responsibility. \\
\hline $\mathrm{g}$ & An ability to communicate effectively. \\
\hline $\mathrm{h}$ & $\begin{array}{l}\text { The broad education necessary to understand the impact of engineering } \\
\text { solutions in a global and societal context. }\end{array}$ \\
\hline $\mathrm{i}$ & A recognition of the need for and an ability to engage in life-long learning. \\
\hline $\mathrm{j}$ & A knowledge of contemporary issues. \\
\hline $\mathrm{k}$ & $\begin{array}{l}\text { An ability to use the techniques, skills and modern engineering tools necessary } \\
\text { for engineering practice. }\end{array}$ \\
\hline $\mathrm{l}$ & $\begin{array}{l}\text { An ability to apply advanced mathematics through multivariate calculus and } \\
\text { differential equations. }\end{array}$ \\
\hline $\mathrm{m}$ & A familiarity with statistics, linear algebra and reliability. \\
\hline $\mathrm{n}$ & $\begin{array}{l}\text { An ability to work professionally in both thermal and mechanical systems areas } \\
\text { including the design and analysis of such systems. }\end{array}$ \\
\hline $\mathrm{o}$ & $\begin{array}{l}\text { A knowledge of contemporary analytical, computational, and experimental } \\
\text { practices. }\end{array}$ \\
\hline $\mathrm{p}$ & A competence in experimental design, data collection, and data analysis. \\
\hline A competence in the use of computational tools. \\
\hline
\end{tabular}




\begin{tabular}{|l|l|}
\hline $\mathrm{r}$ & Knowledge of chemistry. \\
\hline $\mathrm{s}$ & Knowledge of calculus-based physics. \\
\hline
\end{tabular}

Table 2. ME Program Educational Objective and Expected Educational Outcomes.

\begin{tabular}{|l|l|}
\hline $\begin{array}{l}\text { ME } \\
\text { Educational } \\
\text { Objective }\end{array}$ & $\begin{array}{l}\text { To provide students with the necessary preparation in mechanical } \\
\text { engineering to compete effectively for professional careers in this field } \\
\text { and with the motivation for personal and professional growth through } \\
\text { lifelong learning. }\end{array}$ \\
\hline $\begin{array}{l}\text { Expected } \\
\text { Educational } \\
\text { Outcome }-1\end{array}$ & $\begin{array}{l}\text { The student will demonstrate the necessary competencies in } \\
\text { fundamental engineering technologies in areas of mechanical } \\
\text { engineering, such as: thermal and mechanical systems design. }\end{array}$ \\
\hline $\begin{array}{l}\text { Expected } \\
\text { Educational } \\
\text { Outcome }-2\end{array}$ & $\begin{array}{l}\text { The student will demonstrate competencies in experimental testing, } \\
\text { error analysis, laboratory safety, data acquisition, instrumentation and } \\
\text { laboratory report writing. }\end{array}$ \\
\hline $\begin{array}{l}\text { Expected } \\
\text { Educational } \\
\text { Outcome }-3\end{array}$ & $\begin{array}{l}\text { The student will demonstrate computer competency and an intelligent } \\
\text { use of computers as a tool for developing solutions to engineering } \\
\text { problems. }\end{array}$ \\
\hline
\end{tabular}

Table 3. Mapping of the ME Educational Objective and Expected Educational Outcomes for Capstone Design Course (ME470 and ME475) to Criteria (a-s).

\begin{tabular}{|c|c|c|c|c|c|c|c|c|c|c|c|c|c|c|c|c|c|c|c|}
\hline & \multicolumn{10}{|c|}{ ABET Accreditation Criteria (a-k) and additional ME Program Criteria (1-s) } \\
\cline { 2 - 13 } & $\mathrm{a}$ & $\mathrm{b}$ & $\mathrm{c}$ & $\mathrm{d}$ & $\mathrm{e}$ & $\mathrm{f}$ & $\mathrm{g}$ & $\mathrm{h}$ & $\mathrm{i}$ & $\mathrm{j}$ & $\mathrm{k}$ & $\mathrm{l}$ & $\mathrm{m}$ & $\mathrm{n}$ & $\mathrm{o}$ & $\mathrm{p}$ & $\mathrm{q}$ & $\mathrm{r}$ & $\mathrm{s}$ \\
\hline $\begin{array}{c}\text { Educational } \\
\text { Objective }\end{array}$ & $\mathrm{x}$ & $\mathrm{x}$ & $\mathrm{x}$ & & $\mathrm{x}$ & $\mathrm{x}$ & $\mathrm{x}$ & & $\mathrm{x}$ & $\mathrm{x}$ & $\mathrm{x}$ & & & $\mathrm{x}$ & $\mathrm{x}$ & & $\mathrm{x}$ & & \\
\hline $\begin{array}{c}\text { Edu } \\
\text { Outcome-1 }\end{array}$ & $\mathrm{x}$ & $\mathrm{x}$ & $\mathrm{x}$ & & $\mathrm{x}$ & $\mathrm{x}$ & $\mathrm{x}$ & & $\mathrm{x}$ & $\mathrm{x}$ & $\mathrm{x}$ & & & $\mathrm{x}$ & $\mathrm{x}$ & & & & \\
\hline $\begin{array}{c}\text { Edu } \\
\text { Outcome-2 }\end{array}$ & $\mathrm{x}$ & $\mathrm{x}$ & $\mathrm{x}$ & & $\mathrm{x}$ & & $\mathrm{x}$ & & & & $\mathrm{x}$ & & & & $\mathrm{x}$ & & $\mathrm{x}$ & & \\
\hline $\begin{array}{c}\text { Edu } \\
\text { Outcome-3 }\end{array}$ & $\mathrm{x}$ & $\mathrm{x}$ & $\mathrm{x}$ & & $\mathrm{x}$ & & & & $\mathrm{x}$ & & $\mathrm{x}$ & & & & $\mathrm{x}$ & & $\mathrm{x}$ & & \\
\hline
\end{tabular}

In order to evaluate the outcome of the Capstone Design Course (ME470 and ME475) in satisfying the ABET accreditation Criteria 3(a-k), an Assessment Tool Survey was developed as shown in Table 4. The course ME475 offered in Spring semester is a continuation of the course ME470 offered in Fall semester. In this survey, the graduating seniors were asked to provide specific documentation through writing the page numbers of their final ME475 project report where it is documented that they have utilized the skills corresponding to ABET criteria (a-k), and attach it to their final Capstone Design project report. Each team of two or 
three members was asked to complete one survey form. The five instructors of the Capstone Design Course (ME470 and ME475) also made separate assessment as to which of the ABET criteria (a-k) has the individual student satisfied. The individual assessment by the students and the instructors were compiled and averaged for the entire class, and the results are presented in Fig. 1. In this figure, the horizontal axis shows the various ABET criteria and the vertical axis shows the percentage of time each criteria was satisfied. As can be seen from the mapping of Table 3, ABET criteria a-c, e-g and i-k are to be satisfied by this Capstone Design Course, and the students need to satisfy these criteria more than $70 \%$ of the time. In Fig. 1, the average assessments by the instructors are somewhat less than those claimed by the students, but they are more than $70 \%$ for the above mentioned criteria. As the Capstone Design Project utilizes the knowledge learnt in various other courses, hence fulfillment of the ABET Criteria by this design course implies significant accomplishment. As already mentioned, each course of the ME program does not have to satisfy all the ABET criteria, and based on the mapping done by the instructors in Table 3, ABET criteria $\mathrm{d}$ and $\mathrm{h}$ are not required to be satisfied by the Capstone Design course. Yet criteria $d$ and $h$ were included in the survey Table 4, to see the student response. The course grades are given based on the instructors' evaluation. The student survey is done to collect feedback from the students about fulfilling the ABET criteria.

Table 4. Assessment Tool Survey for satisfying ABET Criteria (a-k).

\begin{tabular}{|c|c|c|}
\hline \multicolumn{3}{|c|}{ Mechanical Engineering Department, AAMU } \\
\hline \multicolumn{3}{|c|}{ Team Number: } \\
\hline \multicolumn{3}{|c|}{ Team Members: } \\
\hline \multicolumn{3}{|c|}{ Project Title: } \\
\hline \multicolumn{3}{|c|}{ Date: } \\
\hline \multicolumn{3}{|c|}{$\begin{array}{l}\text { As a requirement of the Project you need to provide specific documentation that shows } \\
\text { where in your report it is documented that you have utilized the following skills. }\end{array}$} \\
\hline & SKILL & $\begin{array}{l}\text { Page } \\
\text { Numbers }\end{array}$ \\
\hline a & An ability to apply knowledge of mathematics, science and engineering. & \\
\hline b & $\begin{array}{l}\text { An ability to design and conduct experiments, as well as to analyze and } \\
\text { interpret data. }\end{array}$ & \\
\hline $\mathrm{c}$ & $\begin{array}{l}\text { An ability to design a system, component, or process to meet desired } \\
\text { needs. }\end{array}$ & \\
\hline $\mathrm{d}$ & An ability to function in multidisciplinary teams. & \\
\hline e & An ability to identify, formulate and solve engineering problems. & \\
\hline $\mathrm{f}$ & An understanding of professional and ethical responsibility. & \\
\hline $\mathrm{g}$ & An ability to communicate effectively. & \\
\hline
\end{tabular}




\begin{tabular}{|c|c|}
\hline $\mathrm{h}$ & $\begin{array}{l}\text { The broad education necessary to understand the impact of engineering } \\
\text { solutions in a global and societal context. }\end{array}$ \\
\hline $\mathrm{i}$ & $\begin{array}{l}\text { A recognition of the need for and an ability to engage in life-long } \\
\text { learning. }\end{array}$ \\
\hline $\mathrm{j}$ & A knowledge of contemporary issues. \\
\hline $\mathrm{k}$ & $\begin{array}{l}\text { An ability to use the techniques, skills and modern engineering tools } \\
\text { necessary for engineering practice. }\end{array}$ \\
\hline
\end{tabular}

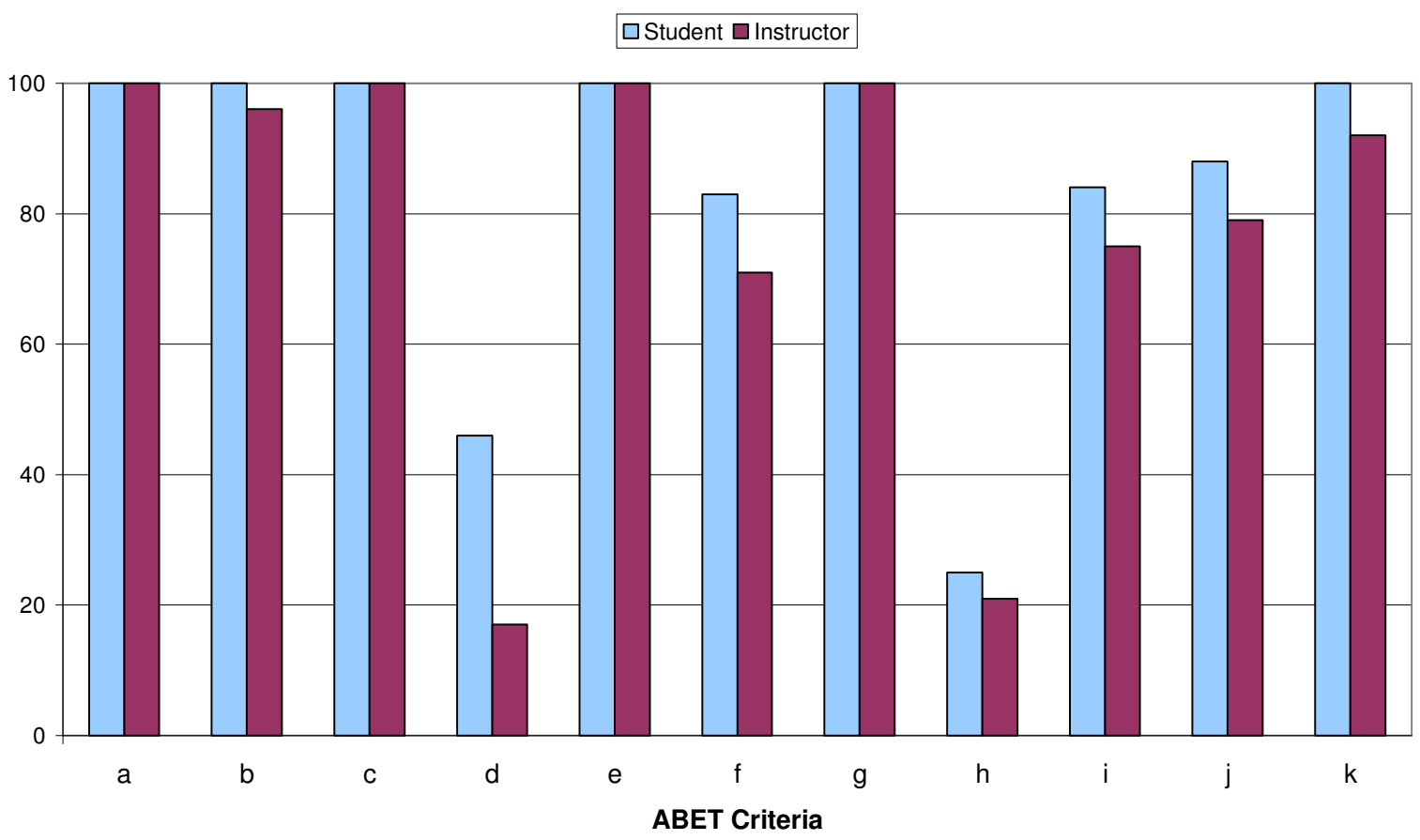

Fig. 1. Assessment Tool Survey response completed by the students and instructors, about fulfillment of ABET Criteria.

\section{Continuous Improvement}

The students have to make several (at least once a month for ME475) oral presentations about their Capstone Design Project in front of their classmates and instructors, using PowerPoint. These presentations are evaluated by their peers and instructors using the evaluation form as shown in Table 5, prepared by the instructors. A scale of $1-4$ has been used, where 1 means poor, 2 means fair, 3 means good and 4 means excellent. About 23 students and 7 facultymembers participated in this survey. The evaluations are compiled and averaged for each 
project group. The averaged evaluations for three arbitrary groups during the ME475 midterm and semester final are presented in Table 6 and also plotted in Fig. 2. In Table 6, the item numbers 1-14 correspond to those queries described in Table 5. During presentation, the instructors give suggestions on how to improve the quality of the project and presentation, and also it gives the student an opportunity to practice presenting in front of a large group of audience. As can be seen in Table 6, for Group-1 the percentage of improvement of the various aspects of final presentation is in the order of about $50 \%$ compared to that for midsemester one. While for Group-3, the improvement is in the order of about 20\%. In Fig. 2, the horizontal axis corresponds to the various item numbers of Table 5, and the vertical axis corresponds to the average evaluation. The figure shows that due to multiple presentations, the performance of the students significantly improves, especially for Group-1. The overall performance of the said three arbitrary groups during the ME475 mid-term and semester final are shown in Fig. 3. Here, the horizontal axis corresponds to some arbitrary group numbers, and the vertical axis corresponds to the points received during the ME475 mid-term and semester final, which will be converted into letter grades. Though the overall performance is based on a number of different factors, but it has direct relation with the project oral presentation. Here, it is found that due to multiple presentation and evaluation by peers and instructors the performance of the students appreciably improves. The overall performance of Group-1 improves from 58 to 80 point, which means a $38 \%$ improvement over their previous grade, while Group-2 and Group-3 has $21 \%$ and $14 \%$ improvement, respectively. As the grade for Group- 1 improves from failing to passing grade due to this continuous evaluation, there will be less student dropping from the program. This improves student retention, will attract more new students, and will help to increase the percentage of minority black engineers in future.

Table 5. Project Oral Presentation Evaluation Form.

Team Members:

Project Title:

Date:

In a rating scale of 1 to 4 ( 1 - Poor , 4 - Excellent), please print a numeral on the right column next to Items $1-14$ below.

\begin{tabular}{|c|c|}
\hline \multirow{7}{*}{$\begin{array}{l}\text { Technical } \\
\text { Presentation } \\
\text { Contents }\end{array}$} & 1. Were the objectives and purpose clearly stated? \\
\hline & 2. Was the problem well defined? \\
\hline & $\begin{array}{l}\text { 3. Was the project Properly justified? } \\
\text { (Scientific, economic, political, value) }\end{array}$ \\
\hline & 4. Was the design, analysis and modeling understood? \\
\hline & $\begin{array}{l}\text { 5. The approach taken was reached as a part of a } \\
\text { selection process? }\end{array}$ \\
\hline & 6. Are the results technically and economically feasible? \\
\hline & 7. Effective conclusions / recommendations? \\
\hline
\end{tabular}




\begin{tabular}{|c|c|}
\hline & 8. Quality of work or design. \\
\hline \multirow{4}{*}{$\begin{array}{l}\text { Presentation } \\
\text { Methods }\end{array}$} & 9. The content was well organized? \\
\hline & $\begin{array}{l}\text { 10. Appropriate use of graphs, charts, board, audio- } \\
\text { video. }\end{array}$ \\
\hline & 11. Was the message clearly delivered? \\
\hline & 12. Teamwork was evident in the presentation. \\
\hline \multirow{3}{*}{$\begin{array}{l}\text { Compliance } \\
\text { Verification }\end{array}$} & 13. Compliance Verification for Mechanical Design part. \\
\hline & 14. Compliance Verification for Thermal Design part. \\
\hline & Total Score $=$ \\
\hline
\end{tabular}

Table 6. Evaluation of three Arbitrary Groups at the Middle and End of semester for ME475.

\begin{tabular}{|c|c|c|c|c|c|c|}
\hline \multirow{2}{*}{ Item \# } & \multicolumn{2}{|c|}{ Group - 1 } & \multicolumn{2}{c|}{ Group - 2 } & \multicolumn{2}{c|}{ Group - 3 } \\
\cline { 2 - 7 } & $\begin{array}{c}\text { Mid- } \\
\text { Semester }\end{array}$ & $\begin{array}{c}\text { End of } \\
\text { Semester }\end{array}$ & $\begin{array}{c}\text { Mid- } \\
\text { Semester }\end{array}$ & $\begin{array}{c}\text { End of } \\
\text { Semester }\end{array}$ & $\begin{array}{c}\text { Mid- } \\
\text { Semester }\end{array}$ & $\begin{array}{c}\text { End of } \\
\text { Semester }\end{array}$ \\
\hline 1 & 2.5 & 3.1 & 3.2 & 3.7 & 3.6 & 4.0 \\
\hline 2 & 2.9 & 3.7 & 3.1 & 4.0 & 3.3 & 3.9 \\
\hline 3 & 2.0 & 3.4 & 2.8 & 3.6 & 3.3 & 3.8 \\
\hline 4 & 2.8 & 3.5 & 3.3 & 3.7 & 3.5 & 4.0 \\
\hline 5 & 1.8 & 3.4 & 2.2 & 3.6 & 3.2 & 3.9 \\
\hline 6 & 2.2 & 3.2 & 2.4 & 3.1 & 2.8 & 3.5 \\
\hline 7 & 1.5 & 3.3 & 2.6 & 3.5 & 3.3 & 3.9 \\
\hline 8 & 1.9 & 3.1 & 2.7 & 3.4 & 3.2 & 3.8 \\
\hline 9 & 2.0 & 3.5 & 3.1 & 3.5 & 3.4 & 3.8 \\
\hline 10 & 2.2 & 3.6 & 2.9 & 3.7 & 3.5 & 4.0 \\
\hline 11 & 1.8 & 3.2 & 3.0 & 3.6 & 3.4 & 3.9 \\
\hline 12 & 2.4 & 3.5 & 2.8 & 3.7 & 3.4 & 3.9 \\
\hline 13 & 2.3 & 3.5 & 2.9 & 3.4 & 3.0 & 3.6 \\
\hline 14 & 2.2 & 3.4 & 3.0 & 3.6 & 3.2 & 4.0 \\
\hline
\end{tabular}




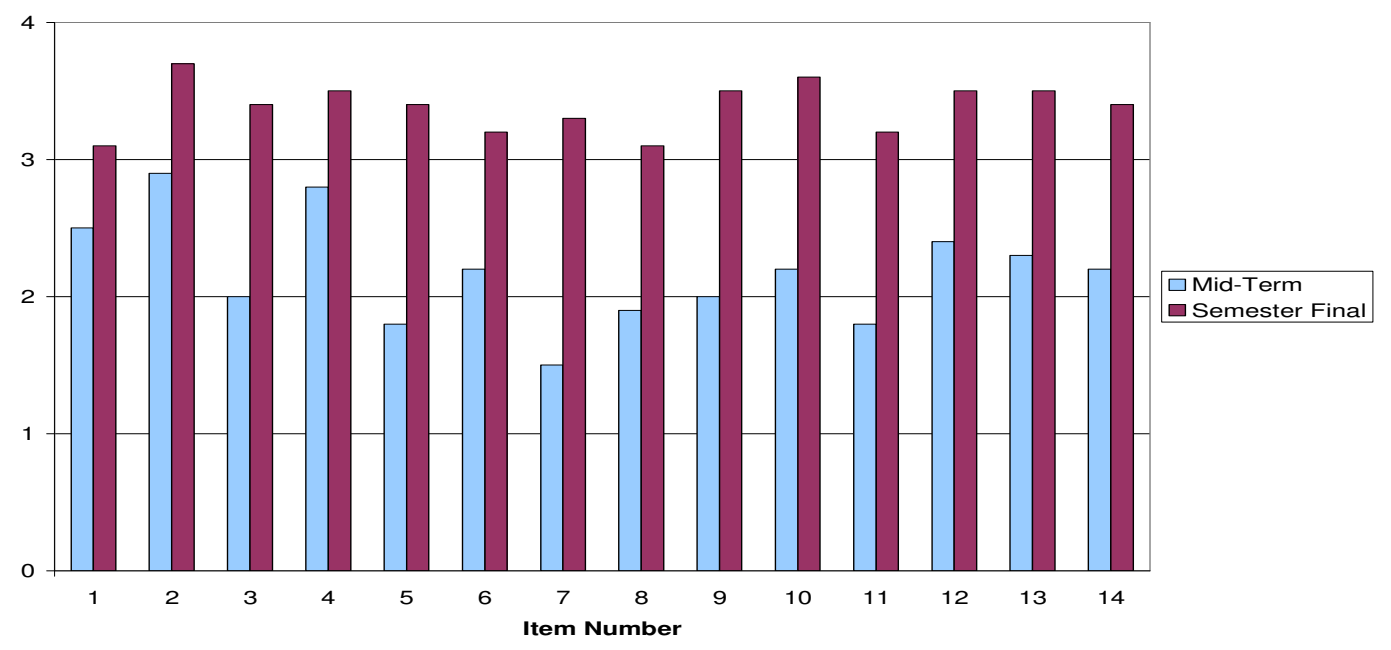

(a) Group - 1

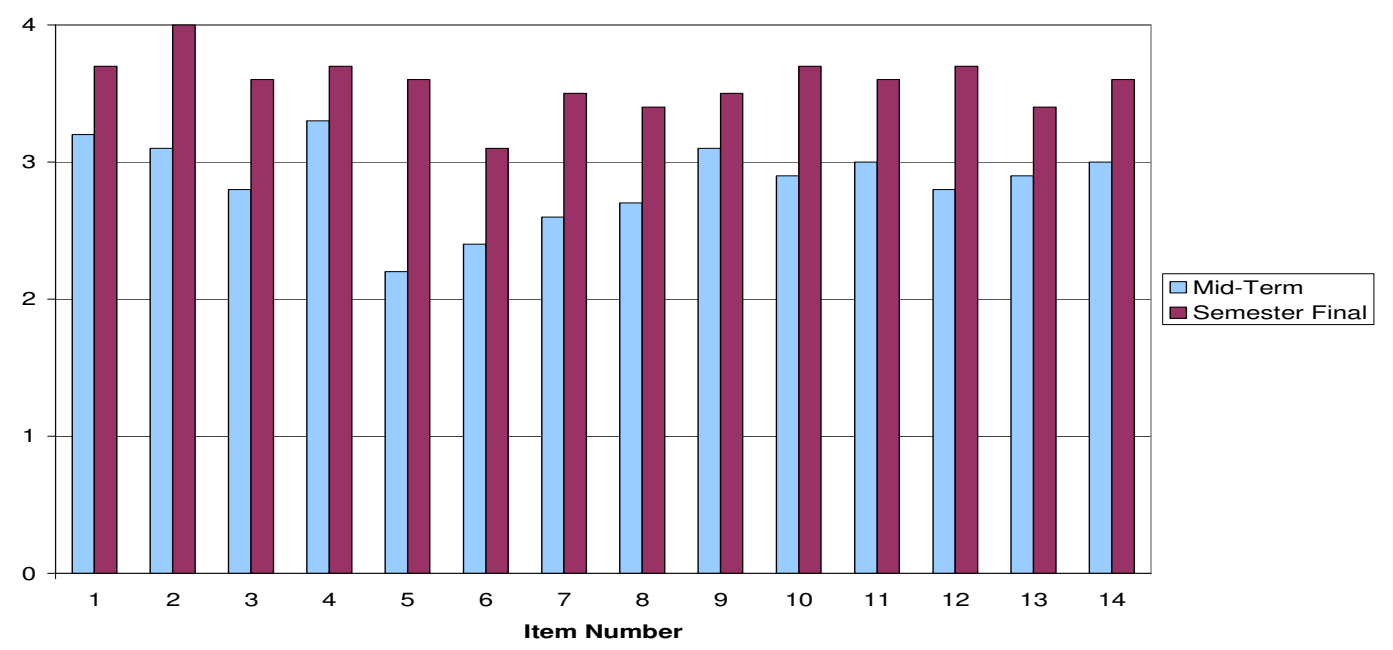

(b) Group - 2

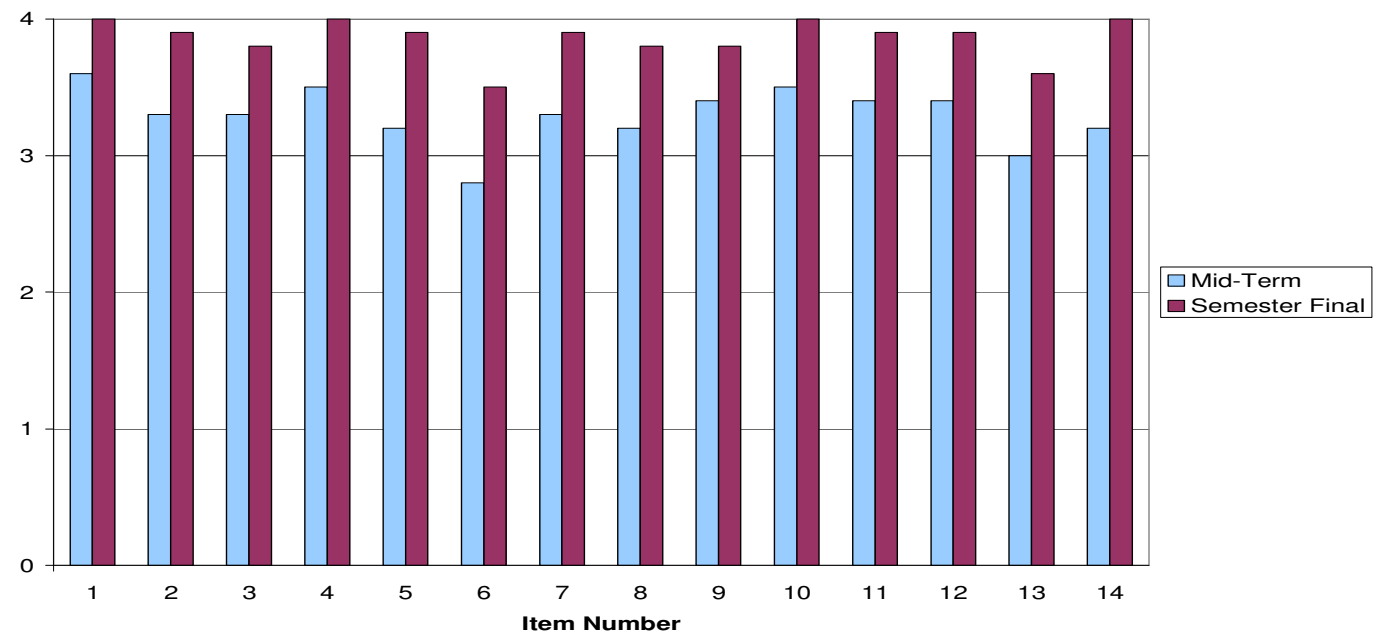

(c) Group - 3

Fig. 2. Evaluation for three Arbitrary Groups at Mid-Semester and at End of Semester. 


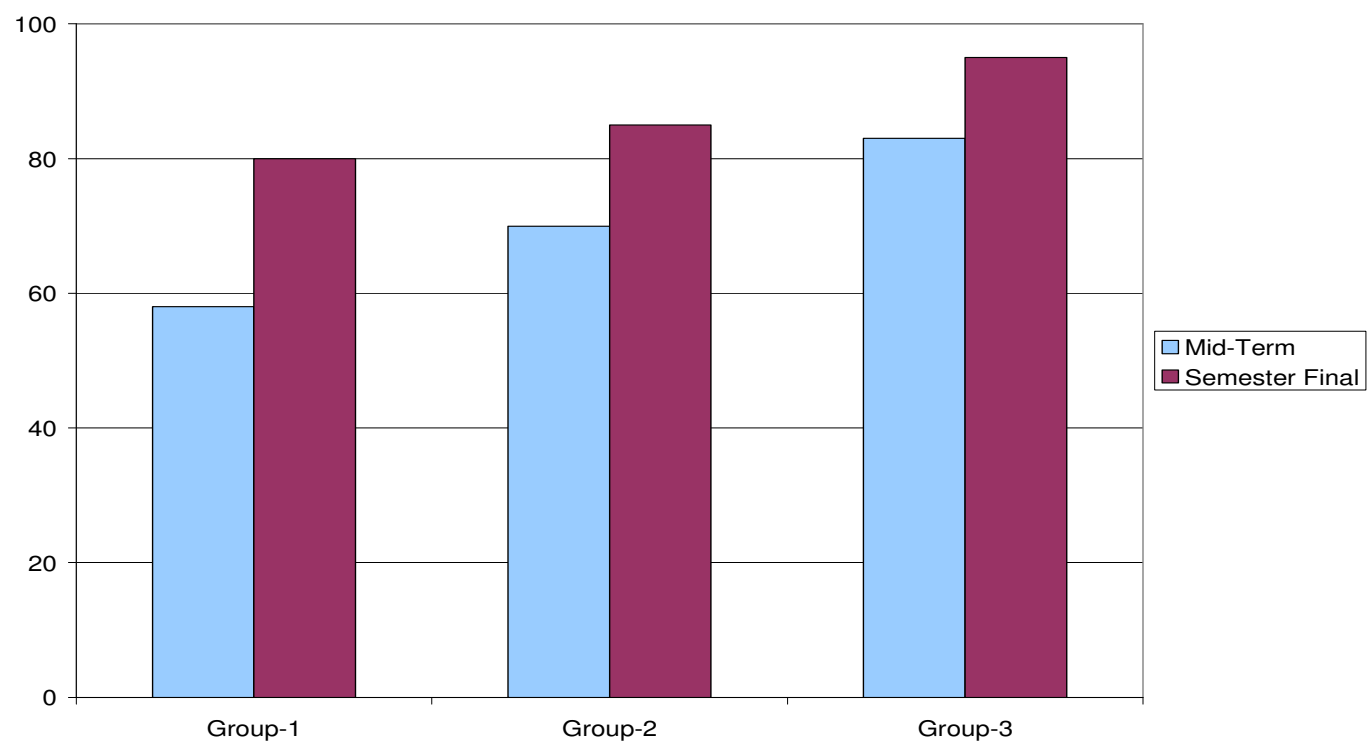

Fig. 3. Student Overall Performance for three arbitrary groups in ME475.

\section{Best Practices for Graduating Engineers}

The industries have some expectation from the new graduating engineers, known as "Best Practices". The ME Capstone Design Course utilizes the knowledge learned by the students in different courses for solving practical engineering problems, and prepare them for the real engineering job. A survey tool was developed in order to determine how successful the Capstone Design Course (ME470 and ME475) were in preparing the new graduating engineers. The graduating students were asked to rate on a scale of 1 to 4 , the impact they believe the Mechanical Engineering Capstone Design Project had in preparing them for some of the "Best Practices" expected from New Graduating Mechanical Engineers, by the industry. The survey results were compiled and averaged, and are plotted in Fig. 4. Here, the horizontal axis denotes the item numbers described in Table 7 , and the vertical axis denotes the average rating by the students. This feedback from the graduating engineers helps to measure the success of the design course in preparing the students to perform as a successful mechanical engineer, and also tells about the areas which probably need more attention. From Fig. 4, it can be seen that, according to the student response the ME Capstone Design Course was very successful in training the students for Teamwork, Communication, etc, but probably need more work in Design for Safety, Environment, Project Management Tool, etc. In future, it is planned to conduct the same survey among the alumni working in different industries, to have their feedback.

Improving performance and preparing the students to be successful in their engineering job, would built the reputation of this ME program, attract more new students (especially minority black students) into the program at this HBCU and discourage the present ones from dropping out. As a result, this will improve student retention and will help to increase the percentage of minority black engineers in the national workforce. 
Table 7. Survey Tool concerning impact of ME Capstone Design Course in preparing fresh graduating engineers.

\section{Mechanical Engineering Department, AAMU \\ Survey Tool for ME Capstone Design Course}

In a scale of 1 to 4 (1- minimum, 4 - maximum), rate the impact you believe the Mechanical Engineering Capstone Design Project had in preparing you for some of the following "Best Practices" expected from New Graduating Mechanical Engineers, by the industry:

\begin{tabular}{|c|l|c|c|c|c|}
\hline Item \# & Description & $\begin{array}{c}\text { Not Agree } \\
(1)\end{array}$ & $\begin{array}{c}\text { Somewhat } \\
\text { Agree } \\
(2)\end{array}$ & $\begin{array}{c}\text { Agree } \\
(3)\end{array}$ & $\begin{array}{c}\text { Strongly } \\
\text { Agree } \\
(4)\end{array}$ \\
\hline 1 & Teamwork & & & & \\
\hline 2 & Communication & & & & \\
\hline 3 & Design for Manufacture & & & & \\
\hline 4 & CAD Systems & & & & \\
\hline 5 & Professional Ethics & & & & \\
\hline 6 & Creative Thinking & & & & \\
\hline 7 & Design for Performance & & & & \\
\hline 8 & Design for Reliability & & & & \\
\hline 9 & Design for Safety & & & & \\
\hline 10 & Concurrent Engineering & & & & \\
\hline 11 & Sketching/Drawing & & & & \\
\hline 12 & Design for Cost & & & & \\
\hline 13 & Systems Perspective & & & & \\
\hline 14 & Project Management Tools & & & & \\
\hline 15 & Design for Environment & & & & \\
\hline 16 & Leadership & & & & \\
\hline 17 & Budgeting & & & \\
\hline
\end{tabular}




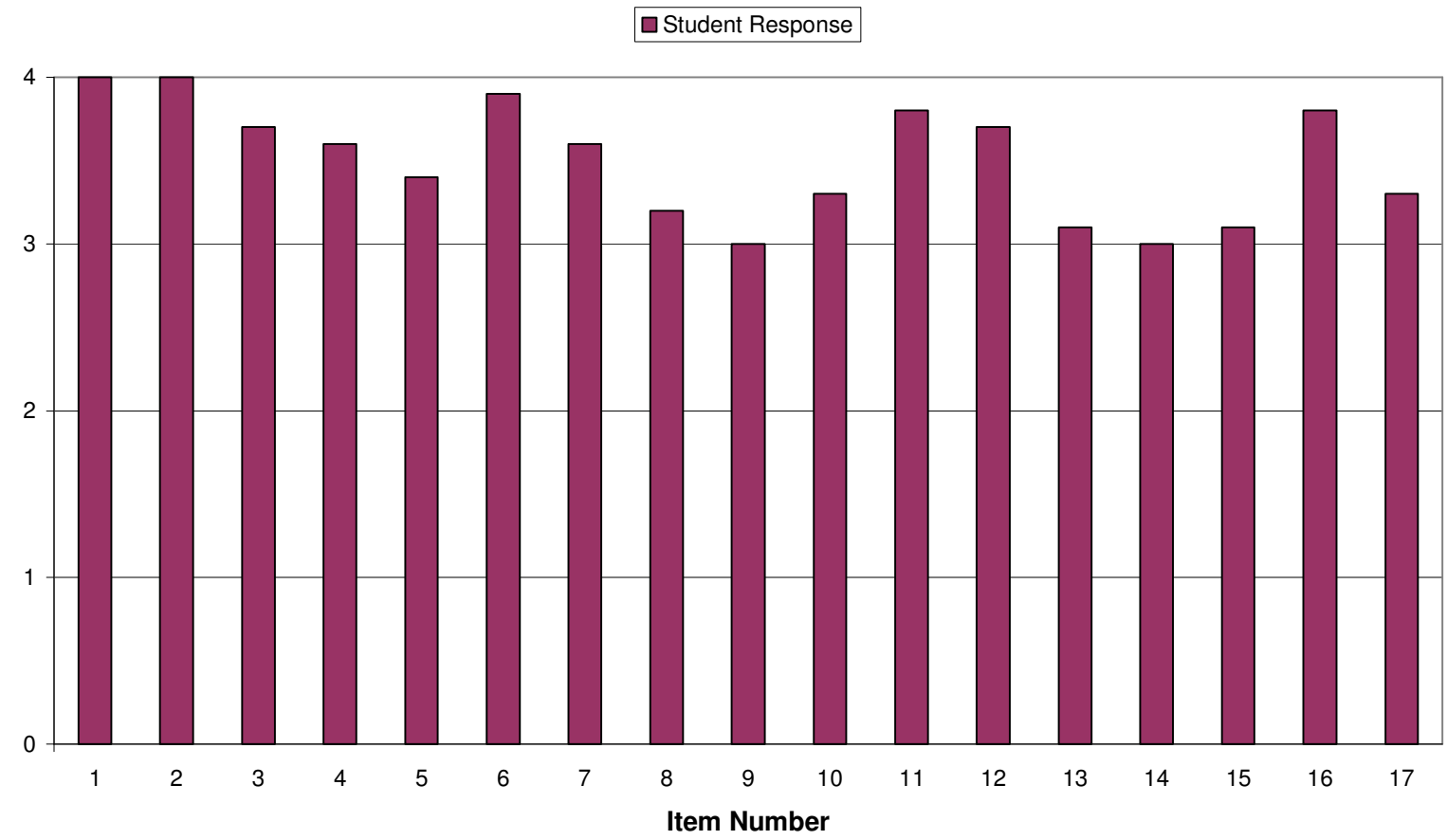

Fig. 4. Survey of Student Response concerning impact of ME Capstone Design Course in preparing fresh graduating engineers for industry.

\section{Conclusion}

This paper explains that the assessment tools used for measuring the outcomes of the Mechanical Engineering program at Alabama A\&M University are based on the ABET requirements and some additional requirements of ASME. The process of mapping the ME Educational Objective and Outcomes for the Capstone Design Course to ABET plus criteria (a-s), tells us about the specific criteria that need to be fulfilled by this course. The Assessment Tool Survey result shows that the mapped ABET criteria are fulfilled by the design course. The multiple Oral Presentation of the Capstone Design project helps to continuously improve the performance of the students significantly. The ME Capstone Design Course also prepares the students to perform as successful new graduating engineers in the industry. Improving performance and preparing for job, would also improve student retention and will help to increase the percentage of minority black engineers in the national workforce.

\section{Bibliography}

1. Engineering Criteria 2000, Third Edition, Engineering Accreditation Commission of the Accreditation Board for Engineering and Technology, December 1997.

2. Taxonomy of Educational Objectives, 1. Cognitive Domain. Bloom, B.S., 1984, New York, Longman. 
3. Implementation of a System Approach for Curriculum Design, Ruben Rojas-Oviedo, Z.T. Deng, Amir Mobasher, A. Jalloh, Mechanical Engineering Department, Alabama A\&M University, ASEE Paper, Session 1566, 2000 ASEE Annual Conference and Exposition, St. Louis, Missouri.

4. Synthesis of Engineering Best Practices and ABET AC2K into a new Mechanical Engineering Curriculum, Ruben Rojas-Oviedo, Z.T. Deng, Amir Mobasher, A. Jalloh, Mechanical Engineering Department, Alabama A\&M University, ASEE Paper, Session 2266, 2000 ASEE Annual Conference and Exposition, St. Louis, Missouri.

5. Evaluation of Assessment tools for Outcome Based Engineering Courses, Z.T. Deng, Ruben RojasOviedo and Xiaoqing (Cathy) Qian, Mechanical Engineering Department, Alabama A\&M University, ASEE Paper, Session 1566, 2003 ASEE Annual Conference and Exposition, Nashville, Tennessee.

6. Effect of Personal Contact in Improving the Outcome of Minority Engineering Students, Showkat J. Chowdhury, Ruben Rojas-Oviedo, Mechanical Engineering Department, Alabama A\&M University, ASEE Paper, Session 1566, 2004 ASEE Annual Conference and Exposition, Salt Lake City, Utah. 